\title{
Making people's lives easier, better and more beautiful - and how computer-aided materials design may help
}

Thomas Kostka

\author{
From 5th German Conference on Cheminformatics: 23. CIC-Workshop \\ Goslar, Germany. 8-10 November 2009
}

Computer-based simulations provide new insights at the molecular scale of chemical processes and material properties - new products may be developed more economically by a more focused strategy. Thus, the overall product development cycle for new materials and active ingredients can be reduced significantly.

R\&D explores and evaluates continuously these possibilities and utilizes the enormous potential linked with scientific computing technologies. The method portfolio ranges from quantum chemical, molecular mechanics and mesoscopic simulations to QSAR approaches.

Examples will be given how scientific computing methods contribute to innovative products with stateof-the-art molecular modeling and mathematical methods - both, for consumer goods and industrial applications.

Published: 4 May 2010

doi:10.1186/1758-2946-2-S1-013

Cite this article as: Kostka: Making people's lives easier, better and more beautiful - and how computer-aided materials design may help. Journal of Cheminformatics 2010 2(Suppl 1):013.

\footnotetext{
Publish with ChemistryCentral and every scientist can read your work free of charge

"Open access provides opportunities to our colleagues in other parts of the globe, by allowing anyone to view the content free of charge." W. Jeffery Hurst, The Hershey Company.

- available free of charge to the entire scientific community - peer reviewed and published immediately upon acceptance

- cited in PubMed and archived on PubMed Central

- yours - you keep the copyright

Submit your manuscript here:

http://www.chemistrycentral.com/manuscript/

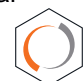
Chemistry Central
} 